\title{
АНАЛИЗ МЕТОДИЧЕСКИХ ПОДХОДОВ К СТИМУЛИРОВАНИЮ ИННОВАЦИОННОЙ ДЕЯТЕЛЬНОСТИ В ВЫСШЕМ УЧЕБНОМ ЗАВЕДЕНИИ
}

\author{
(c) 2020 Лямин Борис Михайлович \\ Высшая школа сервиса и торговли, ассистент \\ Санкт-Петербургский политехнический университет Петра Великого, Россия, Санкт-Петербург \\ E-mail: Lyamin.bm@gmail.com
}

(c) 2020 Моттаева Анджелика Бахауовна

доктор экономических наук, доцент

ГОУ ВО Московской области «Московский государственный областной университет», Россия, Мытищи

Инновационная деятельность профессорско-преподавательского состава является сложной интеллектуальной деятельностью на эффективность которой влияет множество факторов, как внешних (наличие материально-технической базы, материальное стимулирование, научноисследовательская атмосфера в коллективе и т.д.), так и внутренних (желание заниматься инновационной деятельность, наличие необходимых компетенций, способность к непрерывному самообразованию и самосовершенствованию и т.д.). В статье предложена концептуальная модель стимулирования инновационной деятельности. Согласно модели результативность инновационной деятельности работников будет зависеть от четырех компонентов: факторов, оказывающих влияние на инновационную деятельность, инструментов стимулирования инновационной деятельности, требований к результатам инновационной деятельности, системной динамики инновационной деятельности.

Ключевые слова: инновации, стимулирование, научно-педагогические работники, инновационная деятельность, концептуальная модель.

Инновационная деятельность является неотъемлемой частью успешного и активно развивающегося высшего учебного заведения, особенно в условиях возрастания конкуренции на рынке образовательных услуг. Источником реализации инновационной деятельности в рамках университета является научно-педагогический работник. Эффективность инновационной деятельности работника определяется комплексом факторов, таких как:

- организационно-экономические факторы;

- материально-технические факторы;

- научно-инновационные факторы;

- социальные факторы;

- психофизиологические факторы.

Отмеченные факторы непосредственно влияют на эффективность инновационной деятельности работников высшего учебного заведения, соответственно от уровня развития факторов будет зависеть продуктивность научно-педагогического персонала, вместе с тем, эффективное управление факторами может привезти к существенному повышению результативности научно-исследовательской работы работников высшего учебного заведения. В связи с этим стоит рассмотреть применяемые методы управления факторами с целью стимулирования научно-педагогических работников [13].

Ученые Martina Blaskova and Kristina Trskova из University of Zilina from Slovakia [1] утверждают, что высокий уровень мотивации был достигнут теми сотрудниками, для которых создана атмосфера доверия и дружелюбия с возможностью реализовать свои собственные идеи, то есть сотрудников, менеджеры которых применяют творческое лидерство. Авторы отмечают существование многофакторного воздействия на деятельность научно-педагогических работников и считают одним из важных факторов, обуславливающих эффективность инновационной деятельности работников вуза - стиль руководства.

Таким образом, авторы делают вывод, что чем выше будет мотивация руководства высшего учебного заведения на реализацию творческого лидерства, тем выше будет мотивация и творческий потенциал профессорскопреподавательского состава. 
Ученые Connie Chairunnisa and Ahmad Kosasih [2] провели исследование академической культуры в высшем учебном заведении и выявили, что благоприятная академическая культура оказывает положительное прямое влияние на инновационность научно-педагогических работников и их целеустремленность.

На основании полученных результатов авторы предлагают формировать такую академическую культуру, которая бы поддерживала новаторство научно-педагогических работников, предоставляла бы больше свободы и независимости профессорско-преподавательскому составу в проведении академической деятельности.

Авторы подчеркивают важность влияния академической культуры высшего учебного заведения на инновационную активность профессорско-преподавательского состава, что является важным, но не определяющим фактором. Поддержка новых научных исследований со стороны руководящего персонала важна, но без соответствующей материально-технической базы и финансового обеспечения научнопедагогических работников будет сложно рассчитывать на глубокие научные исследования мирового уровня.

Одним из перспективных способов стимулирования труда научно-педагогических работников является эффективный контракт, описанный Курбатовой М. В. и Левиным С. Н. [9].

Эффективный контракт представляет собой контракт между преподавателем и университетом, который гарантирует высокий уровень вознаграждения за выполнение определенных показателей необходимых вузу.

В частности, в трудовом договоре с каждым работником должны быть уточнены и конкретизированы трудовые обязанности, показатели и критерии эффективности деятельности, размеры вознаграждений, размеры поощрений за достижение коллективных результатов труда, обеспечение прозрачности оплаты труда (условия получения вознаграждений должны быть понятны работодателю и работнику и не допускать двойного толкования).

В настоящее время систему эффективных контрактов применяют ряд вузов, таких как МФТИ, МИСиС, НИУ «Высшая школа экономики», национальный исследовательский ядерный университет «МИФИ», «Санкт-Петербургский политехнический университет Петра Великого», «Уральский федеральный университет», нацио- нальный исследовательский «Томский государственный университет», «Новосибирский национальный исследовательский государственный университет» и др.

Опыт стимулирования научно-педагогических работников через заключение взаимовыгодного контракта с преподавателем на примере Высшей школы экономики разработки рассматривает доктор экономических наук Назарова Инна Борисовна. В настоящее время по условиям контракта взаимные обязательства преподавателя и НИУ Высшая школа экономики включат в себя [12]: обязательства вуза предоставить научно-педагогическому работнику не только финансовое обеспечение, но и создать необходимые условия для эффективной работы; требования к учебно-методической, административной и научно-исследовательской деятельности работника; для преподавателей имеющих публикации в журналах входящих в международные базы Scopus или Web of Science снижается учебная нагрузка без потери в заработной плате; надбавки 10-50\% за степень $\mathrm{PhD}$ и для членов кадрового резерва вуза в случае наличия у них административной нагрузки; для более эффективной работы из могут предоставляться оплачиваемые ассистенты; наличие оплачиваемого творческого отпуска научнопедагогическим работникам, отработавшим более пяти лет в университете.

Автор выделяет два основных типа контракта для преподавателей, реализующих трек преподавателя и для тех, кто готов выбрать трек преподавателя - «исследователя»:

- контракт преподавателя - «преподавателя» подразумевает, что значительная часть рабочего времени будет посвящена преподаванию и достижениям в данной сфере (60-70\% занятости). Научной работе такие преподаватели могут посвящать значительно меньше времени (10-30\%) и приблизительно столько же усилий отдавать организационной, общественной работе (10-20\% времени).

В рамках данного контракта работнику необходимо в большей степени заниматься преподавательской работой и выполнять соответствующую деятельность (прежде всего, создавать учебно-методические материалы, руководить дипломными работами, руководить магистерскими диссертациями, готовить студентов к участию в российских и зарубежных конкурсах научных работ). 
- контракт преподавателя - «исследователя»: акцент делается на исследовательскую деятельность (60\%-70\% времени), преподавание составляет меньшую долю от общей нагрузки преподавателя (10-30\% времени), организационная, общественная работа будет составлять до 10-20\% времени преподавателя в университете.

Преподаватель - «исследователь» в меньшей степени занят учебной деятельностью, но должен готовить аспирантов к защите, публиковать, например, не менее двух статей в журнале, реферируемом в WOS, SCOPUS и двух статей, индексируемых в Российской базе цитирования (РИНЦ) в два года.

Новые стратегические подходы к стимулированию научно-педагогических работников рассматривает Алавердов А.Р. [4]. В рамках имущественного стимулирования предлагается расширить перечень факторов, влияющих на размер доплат научно-педагогическим работникам. Автор выделяет ряд условий, за выполнение которых научно-педагогическим работникам следует доплачивать $10-25 \%$ от базового оклада. Достижение индекса цитирования соответствующего занимаемой должности, а также за создание и преподавание авторских курсов предлагается доплачивать до $25 \%$. Научно-педагогические работники преподающие дисциплины на иностранном языке могут получать доплату в размере $20 \%$. Если научнопедагогический работник является практикующим специалистов в соответствующей области, то предлагается доплата в размере $15 \%$. Наконец, доплата в $10 \%$ предлагается за руководство студенческим объединением и за использование инновационных образовательных технологий.

В рамках неимущественного стимулирования предлагается реализовать два подхода: первый - повышение эффективности деятельности НПР за счет повышения их квалификации (оплачиваемые стажировки в лучших зарубежных вузах, среднесрочные программы переподготовки с получением соответствующего сертификата и краткосрочные программы повышения квалификации у лучших специалистов отрасли), второй - проведение ежегодных конкурсов.

В рамках выделенных подходов, стимулирование осуществляется на основании полученных результатов и не учитывает имеющиеся компетенции работников и не учитывает возрастной состав профессорско-преподавательского состава. Что может привести к снижению активности молодых преподавателей [3, 7, 10, 11, 14].

Таким образом, рассмотрев существующие методики стимулирования инновационной деятельности профессорско-преподавательского состава, можно отметить несколько общих черт: авторы подразделяют подходы к стимулированию на материальные и нематериальные, что позволяет удовлетворять как финансовые потребности научно-педагогических работников, так и психологические, что важно для работников, осуществляющих инновационную деятельность, однако, в рамках предложенных методик большую часть стимулов будут получать высококомпетентные сотрудники уже имеющие большой опыт в научной деятельности, вместе с тем, ассистенты и молодые преподаватели не обладающие достаточным уровнем компетенций не будут полноправными участниками разработанной системы. В связи с этим, встает вопрос о необходимости дифференцировать научнопедагогический персонал по возрастному и профессиональному признаку, для того чтобы молодые специалисты стремились к самообразованию, повышению своих компетенций и занимались инновационной деятельностью.

Для решения этой задачи была разработана концептуальная модель стимулирования инновационной деятельности сотрудников высшего учебного заведения (рис. 1).

Для эффективного стимулирования инновационной деятельности профессорскопреподавательского состава высшего учебного заведения необходимо учитывать компоненты, правильное взаимодействие которых приводит к получению планируемых результатов инновационной деятельности. Выделим четыре основных компонента стимулирования инновационной деятельности профессорскопреподавательского состава. «Факторы, оказывающие влияние на инновационную деятельность» - будут первым компонентом концептуальной модели. Факторы относятся в большей степени к среде, окружающей научнопедагогического работника. Так, на системную динамику инновационной деятельности профессорско-преподавательского состава будет влиять специфика и состояние внешней среды. K внешней среде можно отнести инновационный потенциал региона, действующие крупные промышленные предприятия, являющиеся потребителями результатов инновационной деятельности, экономическое состояние региона 


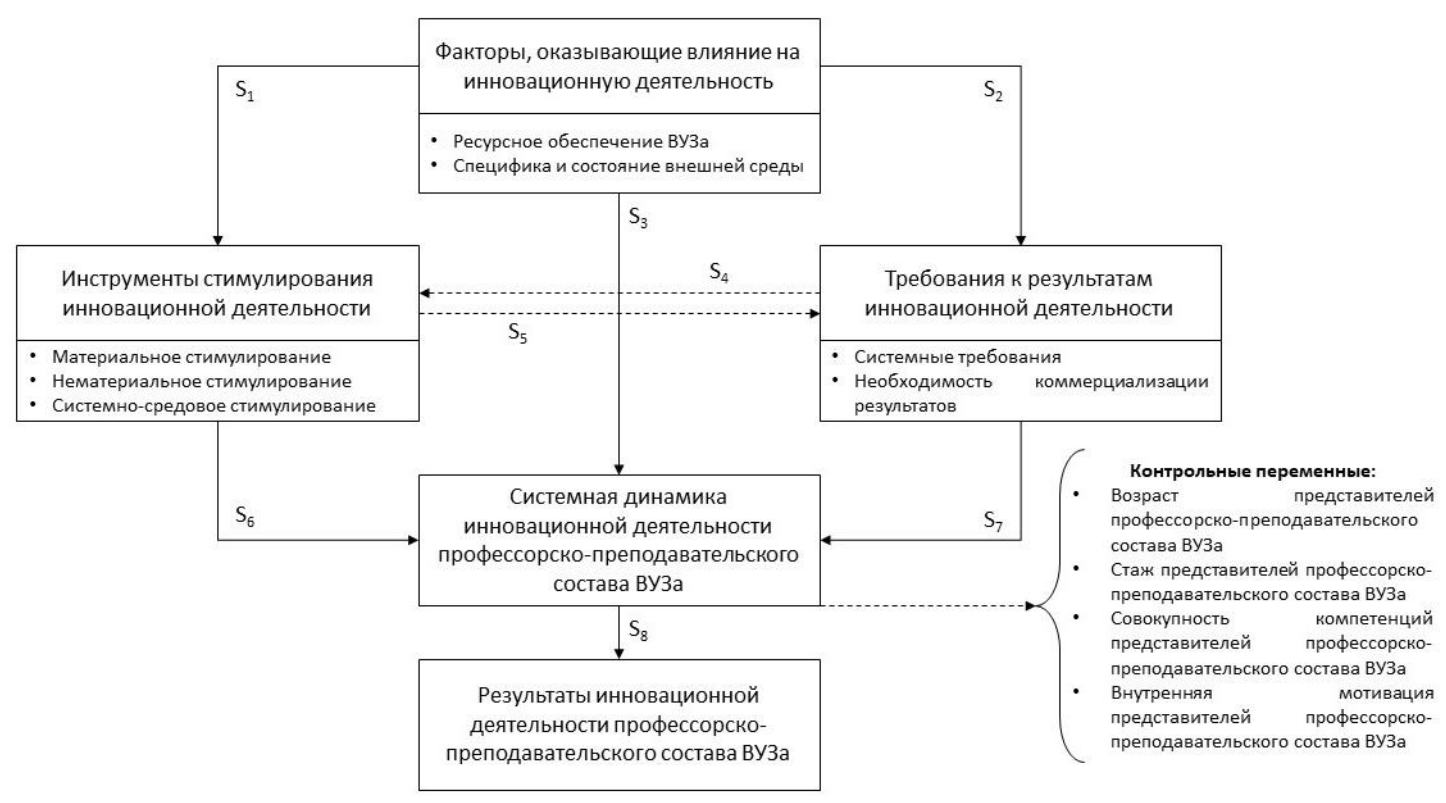

Рисунок 1. Концептуальная модель стимулирования инновационной деятельности сотрудников высшего учебного заведения

и т.д. Наряду с внешней средой на динамику инновационной деятельности профессорскопреподавательского состава будет влиять ресурсное обеспечение высшего учебного заведения, т.е. его материально-техническая база, финансовые, административные и информационные ресурсы. При этом, выделенные факторы будут влиять на второй компонент модели «инструменты стимулирования инновационной деятельности» (S1) и на третий компонент «требования к результатам инновационной деятельности» (S2).

На основании выделенных факторов формируются инструменты стимулирования инновационной деятельности, которые в силу специфики инновационной деятельности будут иметь ряд особенностей. Инструменты стимулирования можно условно разделить на материальные, нематериальные и системно-средовое стимулирование. К материальным инструментам можно отнести уровень финансового обеспечения работников, возможность получения дополнительных выплат за выполнение определенных требований, к нематериальным инструментам можно отнести административное воздействие на работника, например, снижение учебной нагрузки, возможность карьерного роста, повышение квалификации и т.д. Под системносредовым стимулированием можно понимать существующую систему поддержки иннова- ционных идей в коллективе и академическую культуру внутри коллектива. Так, в случае, если в коллективе царит атмосфера взаимопомощи и инновационной активности, то эффективность инновационной деятельности профессорскопреподавательского состава будет на более высоком уровне, чем в коллективах, где предпочитают индивидуализм.

Инновационные разработки, которые будут сгенерированы работниками с учетом влияющих на них факторов, должны соответствовать требованиям к результатам инновационной деятельности. Требования основаны на системных требованиях, которые формируются с учетом существующих отечественных и международных рейтингов, в которых высшее учебное заведение хочет улучшить свои показатели и на необходимости коммерциализации результатов инновационной деятельности, что говорит о востребованности полученных результатов в реальном секторе экономики.

Четвертым компонентом модели будет являться «системная динамика инновационной деятельности профессорско-преподавательского состава высшего учебного заведения», который будет зависеть от следующих факторов:

- возраст представителей профессорскопреподавательского состава высшего учебного заведения;

- стаж представителей профессорско-пре- 
подавательского состава высшего учебного заведения;

- совокупность компетенций представителей профессорско-преподавательского состава высшего учебного заведения;

- внутренняя мотивация представителей профессорско-преподавательского состава высшего учебного заведения.

Таким образом, системная динамика инновационной деятельности профессорскопреподавательского состава будет зависеть от факторов, оказывающих влияние на инновационную деятельность, инструментов стимулирования инновационной деятельности, требований к результатам инновационной деятельности, а также внутренних факторов самих представи- телей профессорско-преподавательского состава. В результате мы получаем планируемые инновационные разработки.

Таким образом, в результате использования концептуальной модели стимулирования инновационной деятельности профессорскопреподавательского состава высшего учебного заведения можно сказать, что результативность инновационной деятельности работников будет зависеть от четырех компонентов: факторов, оказывающих влияние на инновационную деятельность, инструментов стимулирования инновационной деятельности, требований к результатам инновационной деятельности, системной динамики инновационной деятельности.

\section{Библиографический список}

1. Blašková M, K. T. Creative leadership and motivation of university employees // New Trends and Issues Proceedings on Humanities and Social Sciences. 2017. (3). C. 23-34.

2. Connie Chairunnisa C., Ahmad Kosasih K. The influence of academic culture and task commitment toward lecturers'innovativeness // The Journal of Social Sciences Research. 2019. № 12 (5). C. 2413-6670.

3. Lyamin В. [и др.]. Stimulating innovative activities in the university 2020.

4. Алавердов А.Р.Эволюция стратегических подходовк мотивации научно-педагогических работников // Высшее образование в России. 2015. № 5.

5. Байков В.Г., Конников Е. А. Влияние стоимости возможности тестирования инновационного товара на количество привлекаемых испытателей на глобальных интернет-ресурсах // В сборнике: Международная конференция по исследованиям в области обеспечения качества. Сборник научных трудов Международной научно-практической конференции. 2017. С. 125-128.

6. Забелин Б.Ф., Конников Е.А., Мартынов В.И. Методика анализа показателей эффективности управления производственной системой // Экономика и предпринимательство. 2016. № 2-1 (67). С. 955-958.

7. Кобичева А.М., Калинина О. В., Родионов Д. Г. Университет в роли инновационной корпорации // Российский экономический интернет-журнал. 2019. № 4. С. 73.

8. Конников Е.А., Мокейчев Е. В. Три характеристики успешной организации // Казань, 2016.

9. Курбатова М.В., Левин С.Н. Эффективный контракт в системе высшего образования РФ: теоретические подходы и особенности институционального проектирования // Journal of institutional studies (Журнал институциональных исследований). 2013. № 1 (5).

10. Лебедев О.Т., Родионов Д. Г., Мокеева Т. В. Построение организационно-экономического механизма управления жизненным циклом фундаментальных научно-технологических инноваций // Экономика и предпринимательство. 2019. № 5. С. 701-709.

11. Лебедев О.Т., Родионов Д.Г., Мокеева Т.В.Уточнение структуры жизненного цикла фундаментальных научно-технологических инноваций // Вестник Алтайской академии экономики и права. 2019. № 8. С. 71 78.

12. Назарова И. Б. Контракт университета с преподавателем: права и обязанности // Образовательные технологии (г. Москва). 2014. № 3.

13. Седякина А. А., Лямин Б. М., Калинина О. В. Формы стимулирования инновационной деятельности в университетах 2019.С. 643-646.

14. Шевченко Н.Н., Лямин Б. М. Особенности стратегического управления инновационными проектами в современных условиях // Научное обозрение: теория и практика. 2018. № 12. С. 36-43. 